\title{
Mechanical Renovation of Shortgrass Prairie for Increased Herbage Production
}

\author{
L.W. GRIFFITH, G.E. SCHUMAN, F. RAUZI, AND R.E. BAUMGARTNER
}

\begin{abstract}
A study to determine the effects of single ripping, double ripping, and contour furrowing treatments was conducted on shortgrass rangeland in southeastern Wyoming from 1979-1982. The mechanical treatments changed species composition and increased total forage production over the control. Western wheatgrass (Agropyron smithii Rydb.) exhibited increased production on the treated areas compared to the control. Blue grama [Bouteloua gracilis (H.B.K.) Lag. ex Griffiths] production was significantly lower on the double ripping (1981 and 1982) and the contour furrow (1981) treatments than on the control. Needle-and-thread (Stipa comata Trin. \& Rupr.) exhibited an increasing trend on the single and double ripping treatment over the control treatment all 4 years. Forbs also showed his trend in 1979, 1980 and 1981 on all renovation treatments, however little difference in forb production was evident in 1982 . Total production differences were the greatest in the first year of renovation (1979) and in 1980 when the annual precipitation was below the long-term average. Increased livestock carrying capacities would result in payback of the renovation costs in 4 years.
\end{abstract}

Numerous mechanical treatments have been used on rangeland during the past $\mathbf{4 0}$ years to increase herbage production on some range sites. The most commonly used mechanical treatments in the Great Plains are pitting, furrowing, and ripping. Ripping and contour furrowing can increase productivity by disturbing the native sod and shifting the botanical composition to more productive cool-season species (Branson et al. 1966, Rauzi 1975). Success of the mechanical treatments has varied depending on the degree of surface modification. Barnes (1948) found that more than $1.5 \mathrm{~m}$ spacing of furrows for interseeding did not significantly improve forage production. However, Barnes (1952) and Rauzi (1968) noted that spacing furrows no more than $0.6 \mathrm{~m}$ apart and about 10 to $20 \mathrm{~cm}$ deep was the most effective and profitable furrowing treatment. Rauzi (1975) stated moldboard-plow, disc plow, and rotovator treatments increased western wheatgrass (Agropyron smithii Rydb.) by pruning and redistributing the western wheatgrass rhizomes.

To be effective on shortgrass rangeland a treatment should increase water infiltration and storage and reduce competition from unwanted vegetation to allow more desirable cool-season species to become established. Branson et al. (1966) found that the 2 most effective mechanical treatments in increasing forage production and water storage were contour furrowing at intervals of 0.9 to $1.5 \mathrm{~m}$ and depths of 20 to $25 \mathrm{~cm}$, and broadbase furrowing, which consisted of low dikes about $0.5 \mathrm{~m}$ in height. They concluded that effective mechanical treatments modify the soil surface, not the subsoil, to increase retention and storage of precipitation. Wight and Siddoway (1972) and Neff and Wight (1977) found surface modification affects the amount of water available to the plants by preventing runoff, trapping snow, and reducing the number of plants competing for water. The effectiveness of a

\footnotetext{
Authors are agricultural research technican, soil scientist, soil scientist (retired) USDA-ARS, High Plains Grasslands Research Station, 8408 Hildreth Road. Cheyenne, Wyo. 82009, respectively; and area range conservationist, Soil Conservation Service, Torrington, Wyo. 82240.

Acknowledgement is given to $D$. Heyne, district conservationist, Soil Conservation Service, Cheyenne, Wyo., for his assistance in obtaining landowner cooperation and development of the project.

Manuscript accepted May 3, 1984.
}

specific surface treatment was dependent on range site and vegetation characteristics.

Mechanical disturbances of native sod have also resulted in the release of plant nutrients through soil weathering and decomposition of organic matter (Wight and White 1974). They found that western wheatgrass quickly reinvaded disturbed areas and significantly increased total forage production. Changes in species composition resulting from surface modification can be relatively permanent. Wight and Siddoway (1972) noted that abandoned cultivated fields of the Northern Plains became dominated by needle-andthread (Stipa comata Trin. \& Rupr.) and western wheatgrass, resulting in higher production than the contiguous undisturbed range.

Estimations of surface modification longevity range from 15 to 25 years. Rauzi (1974) estimated longevity of range pitting in southeastern Wyoming to be about 15 years, depending on range site, climate, and management. Fisser et al. (1974) stated production on contour furrows would probably remain higher than the untreated native rangeland for at least 20 years. Wight and White (1974) estimated longevity of lister furrows and pits to be 15 and 25 years, respectively.

The purpose of this study was to determine the effects of contour furrowing and ripping of shortgrass rangeland on herbage yields, botanical composition, and livestock carrying capacity.

\section{Methods}

The research was conducted in southeastern Wyoming approximately $13 \mathrm{~km}$ south of Cheyenne. Elevation at the study site is about $1,830 \mathrm{~m}$. The soil is an Ascalon fine loamy mix, a member of the mesic family of Aridic Argiustolls (Young and Singleton 1977). The surrounding area is mostly rolling prairie which is used primarily for livestock grazing. The plot area was nearly level, therefore neither runoff nor runon was a contributing factor. The climate is semiarid with a mean annual precipitation of $36.8 \mathrm{~cm}$; the growing season averages 132 days.

Native vegetation on the study site consisted of blue grama [Bouteloua gracilis (H.B.K.) Lag. ex Griffiths], buffalograss [Buchloe dactyloides (Nutt.) Engelm.], western wheatgrass, needleand-thread, Junegrass [Koeleria cristata (L.) Pers.], and Sandberg bluegrass ( Poa secunda Presl.) with blue grama being the dominate species. Dryland sedges (Carex spp.), annual grasses and forbs were also scattered throughout the plot area. Since western wheatgrass has been shown to respond most dramatically to mechanical treatments, and is used by the Soil Conservation Service as a guide for determining whether mechanical range renovation is feasible, a culm count was made to determine the relative density of that species on the study area. The culm count was made by counting individual culms of western wheatgrass in twenty, $0.093-\mathrm{m}^{2}$ quadrats.

The experimental design was a randomized complete block with 4 treatments: ripped I direction, ripped 2 directions. contour furrowed, and a control. Treatments were established in April 1979 and livestock excluded from the study area. Ripped furrows were spaced $40 \mathrm{~cm}$ apart (Fig. la). One area was ripped at right angles to the first ripping (Fig. $1 \mathrm{~b}$ ). This produced the double ripping treatment. The chisel removed native sod strips 10 to $15 \mathrm{~cm}$ wide and 10 to $15 \mathrm{~cm}$ decp. The single ripping treat ment removed an average of 

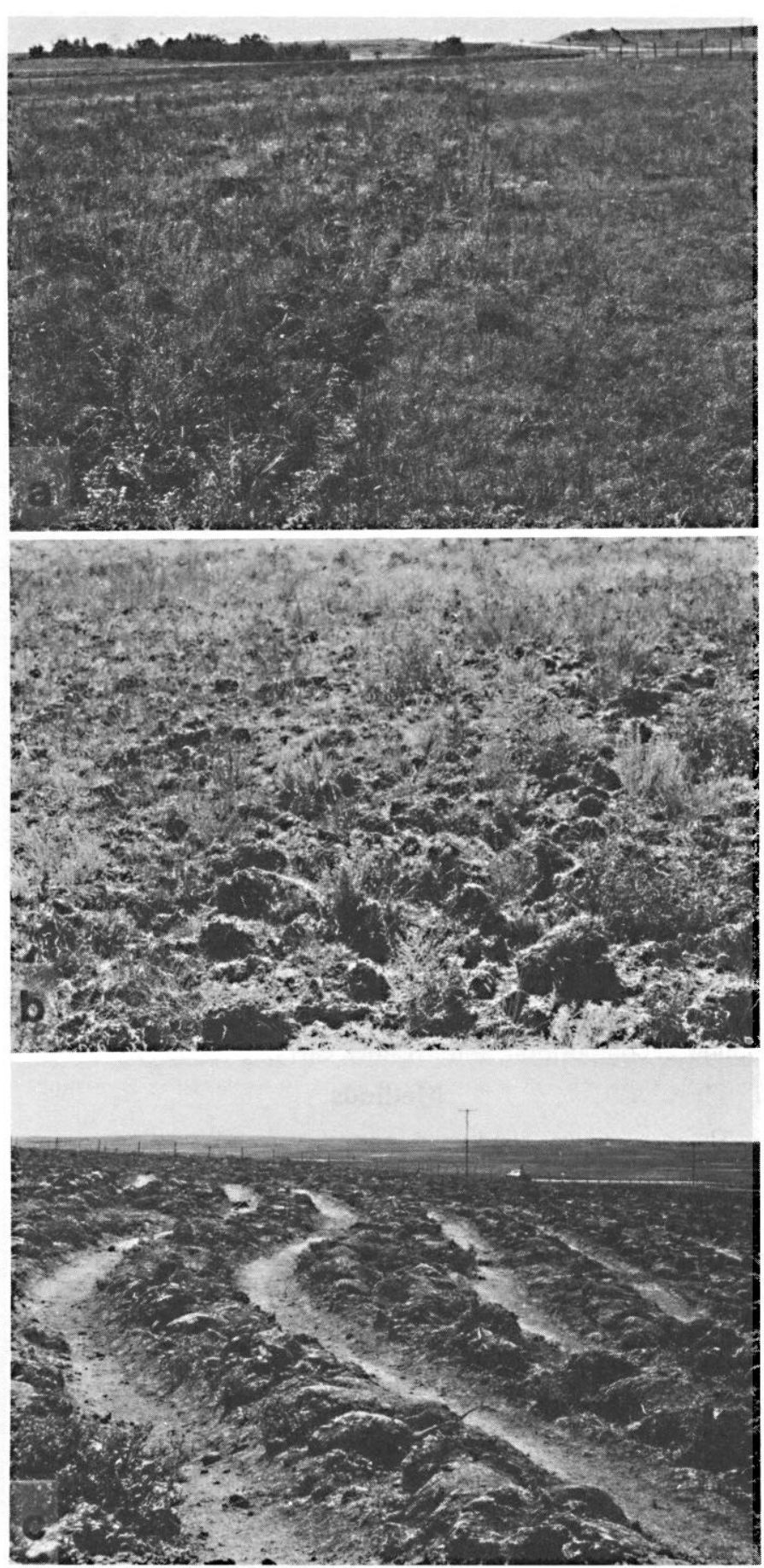

Fig. 1. Mechanical renovation of a shortgrass range site: (a) control and single ripping, (b) double ripping, and (c) contour furrowing.

$28 \%$ of the existing vegetation $(20-35 \%)$, as determined by direct measurement in $1-\mathrm{m}^{2}$ quadrats. The amount of native sod removed by double ripping averaged $60 \%(52-70 \%)$. The double ripping formed a lattice type appearance on the sod.

Contour furrowing was accomplished using a machine developed by the Agricultural Research Service at Sidney, Mont. This machine made 2 furrows $1.5 \mathrm{~m}$ apart, 15 to $20 \mathrm{~cm}$ deep, 60 to $75 \mathrm{~cm}$ wide, and dammed at intervals of about $6 \mathrm{~m}$ (Fig. 1c).

In the spring of each year (1979-1982) five $1.0 \mathrm{~m}^{2}$ cages were randomly placed on each of the treatment areas except the contour furrowing. Three large exclosures, 0.9 by $1.8 \mathrm{~m}$, were randomly located on the contour furrow treatment. The larger exclosures were used because of the wide furrows made by the furrow machine. Herbage within the cages and subplots was clipped at ground and separated by species to estimate peak standing crop (Table 1). Herbage production estimates were made when the major species of the plant community were approaching maturity. Perennial and annual forbs were combined and will be referred to as forbs in the paper. Fringed sagewort (Artemisia frigida Willd.) was included as a forb since it was predominately found as seedlings. Annual grasses were grouped with those perennial grasses that were present in small quantity. This group was referred to as "other grasses." Forage production was estimated by clipping two $0.18-\mathrm{m}^{2}$ plots under each cage on the control, single ripped, and double ripped treatments. Two $0.36-\mathrm{m}^{2}$ plots were clipped from each exclosure on the contour furrowed treatment. The past year's growth was separated from the current year's growth. This separation is quite distinct in this climate; since the previous year's growth is brittle and a bleached-out gray color compared to the tan color of the mature plant material of the current year. The forage samples were dried at $60^{\circ} \mathrm{C}$ for $48 \mathrm{hr}$ and weighed. Analysis of variance was accomplished on the forage production data and LSD.05 used for mean separations.

\section{Results and Discussion}

Total yields and those from major species varied with years and treatments (Table 1). Annual precipitation fluctuated from a low of $35 \mathrm{~cm}$ in 1980 to a high of $49 \mathrm{~cm}$ in 1982 . Precipitation was above the long-term average for 3 of the 4 years of study (Table 2). April, May, and June precipitation probably has the greatest influence on plant growth and yield (Rauzi 1975) and may account for most of the variation in herbage production between years.

In 1979 western wheatgrass production was 4 times greater on the double ripped treatment compared to the control. The single ripping treatment produced slightly less than twice the control, but it was not significantly different from the control because of sample variability. The 1980 western wheatgrass production showed a similar increasing trend over the control in the single and double ripped treatments. Western wheatgrass became the dominate species in the single rip treatment and comprised about one-third of the total production in the double rip and contour-furrow treatments in 1981 and 1982. The response of western wheatgrass to the mechanical renovation treatments evaluated was similar to that reported by Rauzi (1975). Western wheatgrass culm count obtained on the study site $\left(53 \mathrm{culms} / \mathrm{m}^{2}\right)$ was considerably greater than the one rhizomatous native plant per square meter recommended by the Soil Conservation Service (Wyoming) in their "Standards and Specifications for Grazing Land Mechanical Treatment." This standard was developed to insure adequate populations of rhizomatous plants were present to respond to mechanical renovation.

Blue grama showed little change in production in 1979 and 1980. The 1981 and 1982 blue grama production was significantly lower on the double ripped treatment. Production was also significantly lower on the contour-furrowed treatment than on the control in 1981. The average blue grama production exhibited a general reduction for all treatments compared to the control.

Buffalo grass production exhibited an increasing trend for the single and double ripping treatments compared to control over all years.

Needle-and-thread showed a slight trend toward increased production for the single and double ripping treatment. During the last 3 years (1980-1982) needle-and-thread production was as high as 10 times greater on the double ripping treatment than on any other treatment. Abandoned cultivated lands in this region have become dominated by needle-and-thread (Wight and Siddoway 1972). It responds and competes well in a disturbed grasslands environment.

Forb production exhibited a general trend of increased biomass 
Table 1. Herbage production of major species on study area in southeastem Wyoming, 1979-1982.

\begin{tabular}{|c|c|c|c|c|c|c|c|c|}
\hline & $\begin{array}{l}\text { Agropyron } \\
\text { smithii }\end{array}$ & $\begin{array}{c}\text { Bouteloua } \\
\text { gracilis }\end{array}$ & $\begin{array}{c}\text { Buchloe } \\
\text { dactyloides }\end{array}$ & $\begin{array}{c}\text { Stipa } \\
\text { comata }\end{array}$ & $\begin{array}{l}\text { Other } \\
\text { grasses }\end{array}$ & Carex spp. & Forbs & Total \\
\hline & & & & 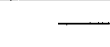 & /ha- & & & \\
\hline \multicolumn{9}{|l|}{1979} \\
\hline Control & 101 & 592 & 83 & 19 & 6 & 18 & 67 & 886 \\
\hline Single Rip & 193 & 333 & 268 & 44 & 15 & 99 & 467 & 1419 \\
\hline Double Rip & 423 & 539 & 401 & 31 & 11 & 39 & 577 & 2021 \\
\hline LSD. $_{.06}$ & 307 & 324 & 358 & 95 & 31 & 64 & 461 & 353 \\
\hline \multicolumn{9}{|l|}{1980} \\
\hline Control & 52 & 510 & 97 & 24 & 0 & 20 & 125 & 828 \\
\hline Single Rip & 352 & 525 & 84 & 122 & 0 & 57 & 409 & 1549 \\
\hline Double Rip & 287 & 578 & 87 & 790 & 189 & 12 & 764 & 2707 \\
\hline LSD.⿻ & 309 & 470 & 174 & 1014 & 281 & 58 & 658 & 794 \\
\hline \multicolumn{9}{|l|}{1981} \\
\hline Control & 74 & 748 & 46 & 10 & 13 & 15 & 110 & 1016 \\
\hline Single Rip & 782 & 609 & 100 & 0 & 55 & 29 & 189 & 1764 \\
\hline Double Rip & 244 & 409 & 166 & 244 & 24 & 24 & 464 & 1575 \\
\hline Contour Furrow & 780 & 296 & 0 & 29 & 9 & 12 & 1060 & 2186 \\
\hline LSD.06 & 509 & 284 & 271 & 181 & 71 & 32 & 313 & 663 \\
\hline \multicolumn{9}{|l|}{1982} \\
\hline Control & 133 & 573 & 0 & 4 & 22 & 20 & 166 & 918 \\
\hline Single Rip & 767 & 467 & 58 & $\mathbf{0}$ & 161 & 4 & 120 & 1577 \\
\hline Double Rip & 428 & 282 & 143 & 307 & 24 & 7 & 164 & 1355 \\
\hline Contour Furrow & 475 & 521 & 0 & 49 & 0 & 0 & 240 & 1285 \\
\hline LSD.06 & 467 & 268 & 206 & 293 & 198 & 17 & 308 & 440 \\
\hline \multicolumn{9}{|l|}{ Average! } \\
\hline Control & 90 & 606 & 56 & 14 & 10 & 18 & 117 & 912 \\
\hline Single Rip & 523 & 483 & 127 & 41 & 58 & 47 & 296 & 1577 \\
\hline Double Rip & 345 & 452 & 199 & 343 & 62 & 20 & 493 & 1914 \\
\hline Contour Furrow & 627 & 408 & 0 & 39 & 4 & 6 & 650 & 1735 \\
\hline
\end{tabular}

The total herbage production of the control, single rip and double rip treatments was averaged over a 4 year period while the contour furrowing treatment was averaged over a 2 year period.

in the single and double ripping treatments compared to the control in 1979-1981. Forb production appeared to be related to the severity of the disturbance of the mechanical treatment. This increase was expected since the treatments disturbed the soil and lessened competition, enabling the annual forbs to become established. However, little difference in production between treatments was evident in 1982. As the desirable species responded to the mechanical treatment the annual forbs accounted for a smaller portion of the total production.

Table 2. Monthly and annual precipitation of study area in southeastern Wyoming, 1979-1982.

\begin{tabular}{|c|c|c|c|c|c|}
\hline & & & & & $\begin{array}{c}\text { Long term } \\
\text { average } \\
\text { mean } \\
\end{array}$ \\
\hline & 1979 & 1980 & 1981 & 1982 & $(1871-1982)$ \\
\hline & & & $-\mathrm{cm}-$ & & \\
\hline JAN & 0.69 & 6.88 & 0.76 & 1.04 & 1.09 \\
\hline FEB & 0.36 & 1.85 & 0.51 & 0.48 & 1.37 \\
\hline MAR & 3.40 & 3.45 & 1.78 & 0.43 & 2.59 \\
\hline APR & 1.96 & 2.36 & 1.85 & 1.35 & 4.42 \\
\hline MAY & 7.37 & 6.07 & 14.40 & 9.04 & 6.20 \\
\hline JUN & 8.43 & 0.18 & 4.22 & 11.48 & 4.52 \\
\hline JUL & 4.65 & 5.08 & 7.24 & 6.88 & 5.03 \\
\hline AUG & 4.72 & 3.94 & 7.37 & 4.60 & 3.84 \\
\hline SEP & 0.81 & 2.46 & 0.79 & 7.29 & 2.92 \\
\hline OCT & 1.17 & 1.30 & 2.16 & 3.05 & 2.21 \\
\hline NOV & 6.30 & 1.17 & 0.23 & 1.09 & 1.35 \\
\hline DEC & 3.81 & 0.20 & 1.14 & 2.11 & 1.14 \\
\hline TOTAL & $\overline{43.67}$ & $\overline{34.94}$ & $\overline{42.45}$ & $\overline{48.84}$ & $\overline{36.68}$ \\
\hline
\end{tabular}

The benefits of the mechanical renovation on forage production are more pronounced in the below normal spring (April-May) precipitation year of 1980 . During the dry years the treatments result in more effective infiltration and storage of the limited precipitation.

The ripped furrows deteriorated by $50 \%$ (sloughed and filled-in) on the fine loamy mix soil during the first 4 months after the initial ripping. However, the furrows weathered very little after that time. Five years after the initial ripping the furrows averaged $5 \mathrm{~cm}$ in depth on both the single and double rip treatments. The contour furrows' width and depth weathered down 35 to $50 \%$ in the first 5 years. Deterioration of the treatments was estimated by comparing initial depth and width measurements of the micro-relief characteristics with those obtained 5 years later. The longevity and effectiveness of the ripped furrows and the contour furrows should last at least an additional 10 years (Fisser et al. 1974, Rauzi 1975, Wight and White 1974). Grazing of the treated areas would reduce the effectiveness and longevity of the treatments.

All 3 mechanical renovation treatments would have resulted in increased livestock stocking rate of this range site. Baumgartner (unpublished data) and Test (1984) estimate that $50 \%$ of the midgrasses and $20 \%$ of the shortgrasses are utilized by cattle. Assuming a $13.6 \mathrm{~kg} /$ day grazing intake, the utilization percentages above and the production from the control, single ripping, double ripping (1979-1982) and the contour furrowing (1981-1982) the stocking rate shown in Table 3 were calculated. The mechanical renovaton treatments generally increased the carrying capacity over the control.

The increases in carrying capacity ranged from 1.3 to 4.8 times the control during the 4 years over all treatments. The single rip treatment resulted in significantly greater carrying capacity in 1981 and 1982 and the double rip treatment was significantly higher than the control in 1979,1980 , and 1982. The contour 
Table 3. Average AUM's per hecture for an untreated and mechanical renovated range site, Cheyenne, Wyo., 1979-1982.

\begin{tabular}{lcccc}
\hline \hline Treatment & 1979 & 1980 & 1981 & 1982 \\
\hline & & \multicolumn{4}{c}{ AUM's/ha -} & \\
Control & 0.49 & 0.40 & 0.51 & 0.49 \\
Single Rip & 0.65 & 0.85 & 1.39 & 1.40 \\
Double Rip & 1.05 & 1.89 & 0.93 & 1.13 \\
Contour Furrow & - & - & 1.13 & 0.90 \\
$\quad$ LSD.06 & 0.36 & 1.08 & 0.60 & 0.33 \\
\hline
\end{tabular}

furrow treatment also resulted in significantly greater carrying capacity than the control. The calculated carrying capacities did not consider the "high protein value" of many of the forbs that would also be utilized in their early phenological stages. Therefore the differences shown would be even greater since the control had the least forb production in all years. Renovation costs average about $\$ 30$ (ripping) and $\$ 40$ (contour furrowing) per hectare and grazing fees range from $\$ 10$ to $\$ 15$ per AUM (R.E. Baumgartner, personal communication); therefore the increased carrying capacities shown in Table 3 would pay for renovation costs in 4 to 5 years. With the reported life of these mechanical renovation practices ranging from 15 to 25 years, these increases in carrying capacity would result in significant economic benefits.

\section{Conclusion}

A study to determine the production effects of single ripping, double ripping, and contour furrowing was conducted on shortgrass rangeland. Ripping enabled the strongly rhizomatous western wheatgrass to reinvade the disturbed area, which increased yield and the potential carrying capacity of the site.

The ripping treatments were the most effective for improving forage production by altering species composition of this site. The competition between forbs and western wheatgrass was strong in both the double rip and contour furrow treatments. Based on production during these 4 years, ripping is recommended over contour furrowing because it is not as costly and could be applied almost anytime of the year with standard farm equipment. However all 3 mechanical renovation procedures resulted in a potential increase in livestock stocking rate. These calculated increases in stocking rate would result in renovation cost payback in about 4 years with continued longer-term economic benefits.

\section{Literature Cited}

Barnes, O.K. 1948. Progress report on some range and grass research, Archer Field Station. Wyoming Agr. Exp. Sta., Wyo. Range Manage. 1. Barnes, O.K. 1952. Pitting and other treatments on native range. Wyo. Agr. Exp. Sta. Bull. 318.

Branson, F.A., R.F. Miller, and I.S. McQueen. 1966. Contour furrowing, pitting, and ripping on rangelands of the western United States. J. Range Manage. 19:182-190.

Fisser, H.G., M.H. Mackey, and J.T. Nichols. 1974. Contour-furrowing and seeding on nuttall saltbush rangeland of Wyoming. J. Range Manage. 27:459-462.

Neff, E.L., and J.R. Wight. 1977. Overwinter soil water recharge and herbage production as influenced by contour furrowing on eastern Montana rangelands. J. Range Manage. 30:193-195.

Rauzi, Frank. 1968. Pitting and interseeding native shortgrass rangeland. Wyo. Agr. Exp. Sta. Res. J. 17.

Rauzi, Frank. 1974. Mechanical and chemical range renovation in southeastern Wyoming. J. Range Manage. 27:48-52.

Rauzi, Frank. 1975. Severe mechanical and chemical range renovation in northeastern Wyoming. J. Range Manage. 28:319-326,

Test, P.S. 1984. Vegetation and livestock responses to three grazing systems - continuous, rotationally deferred, and short-duration rotation. University of Wyoming, Ph.D. Dissertation.

Wight, J.R., and F.H. Siddoway. 1972. Improving precipitation-use efficiency on rangeland by surface modification. J. Soil \& Water Conserv. $27: 170-174$

Wight, J.R., and L.M. White. 1974. Interseeding and pitting on a sandy range site in eastern Montana. J. Range Manage. 27:206-210.

Young, J.F. and P.C. Singleton. 1977. Wyoming General Soils Map. Wyoming Agr. Exp. Sta., Res. J. No. 117.

\section{SRM Election Results}

The Acting Elections Committee Chairman, Jim Free, along with several other Colorado Section members counted the ballots for new officers on Monday, December 10,1984, at the Society for Range Management headquarters.

Elected officers are:

Second Vice President - Jack R. Miller

Directors (1985-1987) - Rex Cleary

\section{Robert Ross}

Directors Cleary and Ross will replace retiring Directors Dwyer and Bedell in February, 1985.

The Bylaw Amendment to include an article on Endowment Fund was approved.

Ballots and tally sheets are retained in the Denver office for one year for review. Approximately $28 \%$ of the membership voted. 